\title{
INTRODUCED LEAFY SPURGE HAWKMOTH, Hyles euphorbiae L., APPEARS IN SASKATOON
}

TYLER J. WIST, City of Saskatoon Pest Management, 1101 Avenue P North, Saskatoon, SK

Leafy Spurge, Euphorbia esula, is a noxious Eurasian weed that infests thousands of acres of range and pasture land in North America. Like many invasive plants, Leafy Spurge is difficult and expensive to control using conventional herbicide treatments. Its milky latex is poisonous to cattle and its highly competitive nature displaces native rangeland grasses, leaving behind an inedible monoculture of 40$80 \mathrm{~cm}$ tall weeds. The latex contains enzymes and toxins that prevent most North American insects from foraging on its leaves. To control Leafy Spurge, an insect specialized to feed on spurge and not on other host plants was looked for in its natural home range. This is an example of classical biological control in which a foreign predator is introduced to control a foreign plant that has become a serious pest. Classical biological control has had several extraordinary successes, such as the introduction of Cactoblastis cactorum to control Prickly Pear Cactus in Australia, but for every one of these successes there are also failures.

The release of the Leafy Spurge Hawkmoth, Hyles euphorbiae L., (Lepidoptera: Sphingidae) was the first of fifteen attempts at classical biological control of Leafy Spurge in North America. In 1961, the Leafy Spurge Hawkmoth was imported from Europe and tested to see if it would eat spurge species native to North America. Larvae of the Leafy Spurge Hawkmoth (Figure 1) seemed to feed primarily on members on the genus Euphorbia and were capable of feeding on both native species originally tested: Spotted

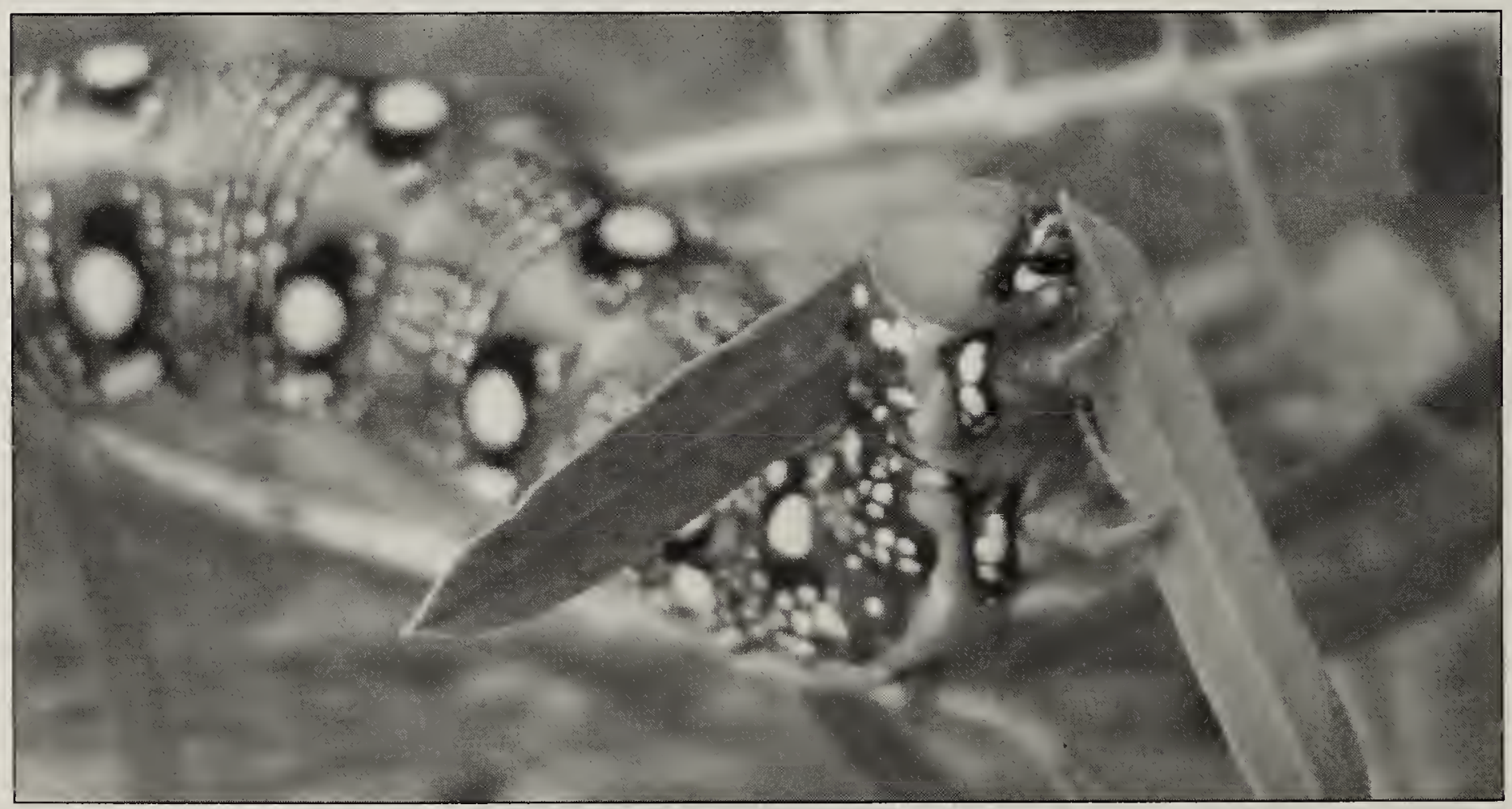

Figure 1. Larvae of the Leafy Spurge Hawkmoth.

Tyler Wist 
Spurge, E. maculata and Snow-on-theMountain, E. marginata. ${ }^{5}$ Based on this, it was hypothesized that the larvae could also feed on the other 108 spurge species that were native to North America. ${ }^{11}$ Despite being only slightly host specific to Leafy Spurge and having the potential to attack the 110 native Euphorbia species, the assessment of the potential for biological control by the Leafy Spurge Hawkmoth continued in North America. It was determined that any Euphorbia species with commercial value such as Poinsettia (E. pulcherrima), or spurge plants with potential for latex rubber production such as the Palo Amarillo tree ( $E$. fulva) would not be in immediate danger from the release of biological control agents against Leafy Spurge. ${ }^{5}$ Insects introduced for classical biological control must go through a rigorous series of quarantines and tests before they are released into their new environment to reduce the possibility of problems with the introduction. Leafy Spurge Hawkmoth larvae performed well and were demonstrated to decimate Leafy Spurge plants when the larvae were sealed together with them in glass containers. ${ }^{1} \quad$ Several exciting demonstrations of their potential for biological control and few questions about their safety in North America led to their approval for release in 1964 and subsequent initial mass release in 1965. ${ }^{1}$

Introduction of the Leafy Spurge Hawkmoth continued across Canada and into several states, and included a release into a stand of Cypress Spurge, E. cyparissias, $^{6}$ in Ontario. Subsequently, Leafy Spurge Hawkmoth populations became established at several sites in Ontario, ${ }^{5}$ New York State $^{2}$ and Montana. ${ }^{5}$ Several Saskatchewan sites were also included in the open release of larvae, including the first at Jameson in 1966 followed by Moose Jaw Creek, Balgonie and Milestone in 1967 and a final release of 600 pupae and 37 larvae at Regina Beach in $1974 .{ }^{5}$

Although Leafy Spurge Hawkmoth populations established at several release sites the species did not realize its potential as a control agent. Often Leafy Spurge Hawkmoth populations established at densities too low to effect any amount of control. ${ }^{6}$ In spite of their large body size and voracious appetites, they did little to keep any of the trial Leafy Spurge populations under control, and the number of adult hawkmoths that were eventually produced was low due to pupal mortality from predation ${ }^{3}$ and diseases introduced from Europe with the larvae. ${ }^{6,12}$ Mice and especially ants were implicated as the worst predators of Leafy Spurge Hawkmoth pupae and larvae. ${ }^{3,4,5}$ The earliest releases had larval mortalities of greater than $95 \%$ within two weeks of release and those larvae that did survive, due to a later release date, developed too slowly to pupate before winter. ${ }^{4}$ Also, Leafy Spurge was adept at re-growing shoots and leaves from its extensive perennial root system, so growth consumed by Leafy Spurge Hawkmoth larvae was quickly replaced. ${ }^{11}$

The hawkmoth had all but disappeared in North Dakota, ${ }^{9}$ one of its original United States release sites and did not appear to be well established in any areas where it was originally released. A glimmer of hope for Leafy Spurge Hawkmoth survival in Canada came from Braeside, Ontario where a population did establish, even though it was below an effective level for control of Leafy Spurge, and spread to Cypress Spurge stands in an $80 \mathrm{~km}^{2}$ radius within five years. ${ }^{5}$ Ten thousand larvae from this Braeside site were 
reared in the laboratory and released in Montana and had, as of 1974, established there as well. ${ }^{5}$ At other sites, released Leafy Spurge Hawkmoth larvae failed to establish and faded away to extinction in the area. For instance, none of the 224 larvae released at Cardston, Alberta in 1978 was recovered. ${ }^{8}$ Undaunted, Leafy Spurge researchers carried on and finally identified several flea beetles that could become established and were effective against Leafy Spurge - but this is a story for another time.

In late August of 2006, a City of Saskatoon weed inspector was surprised to discover dozens of "huge" black, red and orange larvae feeding at one of the two known Leafy Spurge sites in Saskatoon. A larva was brought to the Pest Management Department where technicians identified it as a fifth instar Leafy Spurge Hawkmoth larva. Upon further inspection it was discovered that a colony of Leafy Spurge Hawkmoth larvae was feeding in a small patch of Leafy Spurge in a vacant lot on the corner of Avenue P South and 14th Street West. The first Leafy Spurge bio-control agent had appeared from obscurity in Saskatoon! Scattered reports from across the prairies indicate that the Leafy Spurge Hawkmoth has made periodic reappearances in patches of Leafy Spurge, such as one in Montana, its original United States release site in 1966. ${ }^{7}$ Students in the Davis laboratory at the University of Saskatchewan observed and captured larvae in late spring of 2006 in Douglas Provincial Park where Leafy Spurge infests many acres of land. One of the captured larvae pupated and emerged by the summer suggesting that in South/ Central Saskatchewan at least, Leafy Spurge Hawkmoth may have two generations per year.
The Leafy Spurge Hawkmoth larvae are commonly called "hornworms" in reference to the horn-like structure on their posterior, dorsal end. These larvae appear similar in body plan to the more commonly observed tomato hornworm, Manduca quinquemaculata, but with a strikingly different colour pattern. The fifth instar larvae are black, red, and orange with two conspicuous white dots per segment and numerous smaller white dots set against their orange and black sections (Figure 2, on inside back cover). Interestingly, this patterning still makes these large caterpillars difficult to see in a patch of Leafy Spurge, and their bright red sections probably serve as a warning to predators that these larvae contain Leafy Spurge toxins. Larvae are nearly $10 \mathrm{~cm}$ in length in their final instar before pupation and have a curved red or orange "horn" with a black tip. Larvae have four pairs of prolegs and one pair of anal prolegs. The adult hawkmoth has a wingspan of $5-7 \mathrm{~cm}$ and distinctive pink colouration on the upper surface of its hind wings (Figure 3 , on inside back cover). Commonly referred to as the "Leafy Spurge Hawkmoth" or "Hummingbird" moth because of its feeding habit of hovering over flowers with rapidly beating wings, this diurnal moth visits flowers near patches of Leafy Spurge. It was estimated that there were approximately two dozen Leafy Spurge Hawkmoth larvae within a four metre square patch of Leafy Spurge (6 larvae per $\mathrm{m}^{2}$ ) at the Avenue $P$ site. However this level was below the control threshold of 14 larvae per $\mathrm{m}^{2}$ so it is not surprising that the Leafy Spurge stand seemed unharmed by the hornworm infestation. ${ }^{10}$

The second known patch of Leafy Spurge in Saskatoon is located on the corner of Warman Road and 51st Street on the west side of the Extra Foods 
building. This location did not have any Leafy Spurge Hawkmoth larvae in August of 2006. As a small scale and probably fruitless attempt at biological control, we transferred six larvae from Avenue P to Leafy Spurge plants on 51st Street on August 24, 2006. It was hoped that, given time, the Leafy Spurge Hawkmoth would establish and provide supplementary control of the Leafy Spurge in the area. By August 30 three captive larvae had pupated and all larvae had disappeared from both sites and were presumed to have pupated as well. The origin of the Leafy Spurge Hawmoths found in Saskatoon is unknown and is an interesting mystery to unravel. If a population had indeed established in Montana it is feasible that this site could be the origin of these Leafy Spurge Hawkmoths but it is more probable that our visitors were descendants of those released in the late 1960s in Saskatchewan. It will be exciting to see if the Leafy Spurge Hawkmoth establishes a population in Saskatoon, however, it is more likely that this colourful infestation will serve only to give us a brief glimpse into the history of biological control of Leafy Spurge in North America.

\section{Acknowledgements}

I would like to thank Jennifer Kostyk for working with me to discover more about the Leafy Spurge Hawkmoth, the City of Saskatoon for tracking Leafy Spurge sites, the City of Saskatoon weed inspector, Terri Smith, for bringing us our first larva, and Jacqueline Hulm for her helpful review of this manuscript.

1. ANDERSON G.L., E.S. DELFOSSE, N.R SPENCER, C.W. PROSSER and R.D. RICHARD. 2000. Biological Control of Leafy Spurge: An Emerging Success Story. Proceedings of the $X$ International Symposium on Biological Control of Weeds 15 4-14 July 1999, Montana State University, Bozeman, Montana, USA Neal R. Spencer [ed.]. pp. 15-25.
2. BATRA, S.W.T. 1983. Establishment of Hyles euphorbiae (L.) (Lepidoptera: Sphingidae) in the United States for control of two weedy spurges, Euphorbia esula L. and E. cyparissias L. Journal of the New York Entomological Society 91:304311.

3. FORWOOD, J. R. and MCCARTY, M. K. 1980. Control of Leafy Spurge (Euphorbia esula) in Nebraska with the spurge hawkmoth (Hyles euphorbiae). Weed Science 28(3): 235-240.

4. HARRIS, P. and ALEX, J. 1971. Euphorbia esula L. Leafy Spurge, and E. cyparissias L., cypress spurge (Euphorbiaceae). Pages 83-88 In :Biological Control Programmes Against Insects and Weeds in Canada 1959-1968. Technical Communication of the Commonwealth Institute of Biological Control 4.

5. HARRIS, P. 1984. Euphorbia esula-virgata complex, Leafy Spurge and E. cyparissias L., cypress spurge (Euphorbiaceae). In: Biological Control Programs Against Insects and Weeds in Canada 1969-1980. Kelleher, J.S., and Hulme, M.A. (eds.). Commonwealth Agriculture Bureau. 159-69 pp.

6. HARRIS P., P.H., DUNN, D. SCHROEDER and VONMOOS R. 1985. Biological control of Leafy Spurge in North America. Leafy Spurge, Monograph series of the Weed Science Society of America. ed. Alan K. Watson, . Chapter 8 (3):7992.

7. KNODEL, J. 2006. Leafy Spurge Hawkmoth. North Dakota State University Crop and Pest Report 11:2.

8. MCCLAY, A.S., D.E., COLE, P. HARRIS and RICHARDSON, C.J. 1995. Biological Control of Leafy Spurge in Alberta: Progress and Prospects Biological Control of Leafy Spurge in Alberta: Progress and Prospects. AECV95-R2, 63 pp.; 29 ref.

9. MESSERSMITH, C.G. and LYM, R.G. 1990. Leafy Spurge control: 10 years of research enhancement. North Dakota Farm Research. 47(6):3-6.

10. NEW, T.R. 1971. The consumption of Euphorbia cyparissias (Euphorbiaceae) by larvae of Celerio euphorbiae (Lepidoptera: Sphingidae). Canadian Entomologist. 103:59-66.

11. PEMBERTON, R.W. 1984. Native plant considerations in the biological control of Leafy Spurge Proceedings of the VI International Symposium for the Biological Control of Weeds. August 19-25 1984, pp. 365-390.

12. SPENCER, N.R. 1994. Imported insect establishment for Leafy Spurge (Euphorbia esula) control. Proceedings of the Great Plains Agriculture Council, Lincoln, NE: The Council. 1994. pp. 13-17. 